\title{
An Investigation into the International Business Growth Challenges faced by a South African Manufacturing Company
}

\author{
MICHAEL NKOSINATHI SHANDU \\ Mancosa Graduate School of Business, 16 Samora Machel St, Durban Central, \\ Durban, 4001, South Africa. \\ Email: publications@mancosa.co.za \\ SHASHONA SINGH \\ Mancosa Graduate School of Business, 16 Samora Machel St, Durban Central, \\ Durban, 4001, South Africa. \\ Email: publications@mancosa.co.za
}

\begin{abstract}
A South African manufacturing company opened its head office in Africa about four decades ago. Over the years, the company has been doing business with the rest of Africa through exporting and had reached a point where it needed to consider other ways of expanding its business across the continent. The purpose of the study was to investigate the international business growth challenges the firm faces. The study employed a qualitative methodology where eight managers were purposively selected from 22 managers engaged in international assignments. Thematic analysis was used to analyse the data gathered from the interview narratives. The study findings revealed that the company conducted its business by way of exporting its products into Africa and created resources for the countries it had business with while benefiting from technology and innovation transfer in the long-run. However, the firm suffered political interference, language barriers, and corruption, as some of the serious hindrances of doing business across the continent. In addition, the study concluded that international business success depended on politics and the economy, calling for organisations engaged in international assignments to cautiously expand their business beyond borders. The study recommended that a similar study is conducted in other organisations that do business with the rest of Africa in order to obtain a balanced view of the growth challenges.
\end{abstract}

Keywords: Export Business, Innovation Transfer, International Business Growth.

\section{Introduction}

The attainment of political independence by South Africa ushered in a new era where the majority of South African firms embarked on international expansion, which was not possible during the apartheid regime. This manufacturing company began its international expansion drive in the mid-90s with the view to doing business in the African continent and beyond. While the firm has been doing well in expanding its footprint over the years, management seeks to triple its expansion efforts, which is seemingly becoming a challenge. This study, therefore, seeks to investigate the international growth challenges faced by this company.

\section{Background to the Problem}

The organization employs approximately 25,000 employees and is located in over 30 countries across the globe. The group has its main functions located in central Europe, Russia, North America and South Africa. The firm exports products across the African continent and has grown from being a small manufacturing 
firm in the nineties to a vast manufacturer and supplier of products across Africa and beyond (Farrell, 2007). Despite enjoying expansion across the African region, the manufacturing giant seeks to triple its expansion by $60 \%$ percent into the African market. Increasing its market share across Africa will definitely grow its business. Unfortunately, business expansion is a challenge amidst other challenges of doing business elsewhere across Africa. According to a company report, the growth of the firm largely depends on the firm's ability to deal with international growth challenges.

\section{Research Questions}

The questions are in line with the objectives of the study and are as follows:

- What are the international business opportunities across the African continent for the company?

- What are the factors affecting the company's international business growth into Africa?

- To what extent do the factors hinder international growth into Africa?

- What recommendations would be made to senior management towards boosting international business growth strategies into Africa?

\section{Significance of the Study}

This study is significant in three ways. Firstly the study inculcates a sense of reactiveness to the business managers towards coming up with the means of improving the company's growth and expansion strategy. If the company increases its footprint across Africa, this will positively contribute to profitability, growth and the creation of more jobs and in the overall benefiting South Africa's economy. From an academic side, the study may contribute to the existing business knowledge, therefore, contributing to some empirical studies. This study will not adopt an existing interview guide but will rather develop a fresh instrument that could be used for similar studies, hence a significant contribution to academia. The local economy will be the main beneficiary to the expansion drive through employment creation, and to some extent through corporate social responsibility, as the company will reinvest some of the proceeds from international expansion into the local economy.

\section{Literature Review}

The World Trade Organization (WTO) defines international business growth as the process by which an organization seeks to increase its involvement in international operations. This definition suggests how firms enter and serve markets in foreign lands (Goldstein, Rivers \& Tomz, 2007). According to the WTO, international growth entails the process of increasing integration within the world economy with certain drivers taking a centre stage in ensuring such expansion or growth into the international market. According to Varghese (2011:101), any firm that enters and serves foreign markets does engage in some form of international business. The process of moving from the domestic market is referred to as internationalization (Steger, 2009).

International management is critical for the reason that countries differ in various respects that include the culture, politics, rules and regulations, economic systems and levels of economic development (Hill, 2009). While there is much interest from the business community to take the international business to the next level, differences that exist among countries are increasingly becoming an obstacle to international business growth. For example, the culture of the South African people is different from the culture of the West African countries. This has serious implications for a firm engaging in international business. It is therefore critical to note that international expansion includes the following: 
Expanding business across Africa and beyond;

Understanding the difference between the local and foreign markets and the move to develop and embrace the international outlook of the business;

Identifying the production and other physical facilities in the international market;

Using international markets as the basis for planning the developments and production of products;

Regarding the international market as the basis of factors of production, for instance, raw materials and labor;

Redesigning the structure and culture of the firm culture in line with the international best practice.

Hamilton and Webster (2009:16) highlight that the variations amongst countries compel an international firm to vary its ways of doing business from country to country in order to be relevant. For example, marketing products in South Africa may require different approaches in Nigeria, Kenya, and Zimbabwe etc. Managing South Africa workforce might require different managerial skills from managing Zimbabweans or other nationalities and maintaining relations within different countries may be important in one country and less in another. It is therefore critical that international business managers understand the international expansion or growth environment as they are compelled to understand competitors mindful of the fact they will compete with a foreign firm in the local market (Freidman, 2008:49).

According to Hui, Needy and Higbee (2008:770), foreign direct investment (FDI) also influences international business. FDI refers to all investments by a firm outside its home country (Head \& Sorenjen, 2005:309). In addition to the reduction in trade barriers, many countries have progressively removed the restrictions on FDI. According to Golstein, et al., (2007: 39) there has been an increase in bilateral relations that seek to promote investment amongst nations across the globe in the form of FDI. It is through FDI, that technology transfers were successful across various nations. Thus, information technology plays a key role in international business. For example, microprocessors have been at the center of the technology enabling rapid international business growth and expansion.

Hill (2009) notes that advances in transportation were critical for promoting international business. The development of commercial jet aircraft for instance so a huge improvement in international business, which enabled firms to reduce the time required to move from one country to another followed by transportation of heavy goods over long distances (Donnison, 2008:99). Before transport developments, moving goods was labor intensive, lengthy and costly leading to the idea of engaging in international business.

According to Hill (2009), the establishment of regional trade agreements influenced international business expansion as regional and cooperation agreements influence competition among firms. Therefore, moves towards promoting regional integration of economies such as Southern African Development Community (SADC), the Economic Community of West African States (ECOWAS) and the Common Market for Eastern and Southern Africa (COMESA), are some of the regional economic organizations in the African continent, which influence international business. These bodies promote internationalization. Specifically, internationalization refers to how firms enter and serve foreign markets (Hill, 2009). Hill (2009) argues that internationalization means the same as international business. What is however critical is that international expansion of firm occurs when certain factors referred to as push and pull factors are present. For example, the company under study can decide to expand across Africa - this happens due to the pull factors. Pull factors represents all the outside factors out of South Africa. The pull factors according to (Hill, 2009) are the factors that pull the company so the firm can invest there. The push factors originate in South Africa and they push this company out of the country. The pull factors for international business include:

The potential for expanding market opportunities.

The potential for lower costs of production elsewhere.

Less regulation elsewhere.

Potential for high profits. (Donnison, 2008:99). 
The push factors for internationalization are:

Market saturation

Increasing cost of production.

Rivalry competitive practices in the domestic market.

Inadequate economies of scale. (Pavlova, 2014).

International business has exponential benefits as outlined by Shekshnia, Ledeneva and Denosova Schmidt (2014). Thus, international business is well known for bringing resources that include technology and new skills to the host countries. The introduction of technology and skills will obviously improve the country's production capacity, which in the long run will result in increasing productivity and reducing prices. Further, technology transfer has the potential to facilitate innovation as home countries get ideas from other countries.

Despite the advantages, Hill (2009) argued that international business could bring more harm than benefits if not carefully approached. For example, there are several protests from civil society against international business, citing the dumping of cheap products into developing countries all in the name of conducting international business. According to Radziwill and Vaziova, (2015), international business is criticized for the loss of jobs in the recipient country and complaints against environmental degradation caused by foreign firms pursuing profits with little regard for the protection of the environment.

\section{Factors Affecting International Business/Growth}

International business is affected by a multitude of factors. According to Glasse, (2010) several factors briefly referred to as the SLEPT factors affect the extent to which a firm engages in international business in the respective countries. For a firm to succeed in the international market, it ought to identify, appraise and respond to the business environment in the respective countries (Glasse, 2010). The factors forming the SLEPT analysis include the following:

\section{The Social Environment}

The social environment of the firm consists of factors such as consumer lifestyles, habits and values formed by culture, which exert certain demands on the firm particularly through consumerism (Donnison, 2008:99). There are several important issues in a society that affects business. These are customer preferences, habits, beliefs and etiquette. These become more complicated as firms go international.

Regarding consumer preferences, habits and beliefs, the argument is that products or services that are popular in one culture may not be liked in another culture. Firms usually improve their products and services to match the tastes and preferences of consumers in foreign countries where they operate. There are major differences in the tastes and preferences of products or services in various countries. These differences may even exist within large countries that have different cultures like Nigeria. (Donnison, 2008:99). The marketing must be designed to suit the environment and characteristics of the market.

In order to be successful, a business must design its strategy so that it is relevant to the socio-cultural environment in which it operates. It is important to note that although people of different cultures may use the same basic product or service, differences in the way they consume may still exist. The perceptions on the attributes may also vary significantly to the extent that the method of promoting the product may be varied to match the different markets. Etiquette entails the mannerisms of a people or a society in relation to how they approach one another when they meet and greet (Cherunilam, 2003). What is regarded as the right behavior in one culture may be offending in another culture. Managers ought to take these cultural issues into account as they move from country to country. Culture is a complex factor viewed as critical in international expansion (Cherunilam, 2003). Culture is the values, ideas, attitudes and behavior of a 
particular nation or country generally differentiated through the determinants of a culture. The determinants include religion, political philosophy, economic philosophy, social structure, language, and education as illustrated in figure 1 below. It must be emphasized that culture changes over a period as the determinants of culture change.

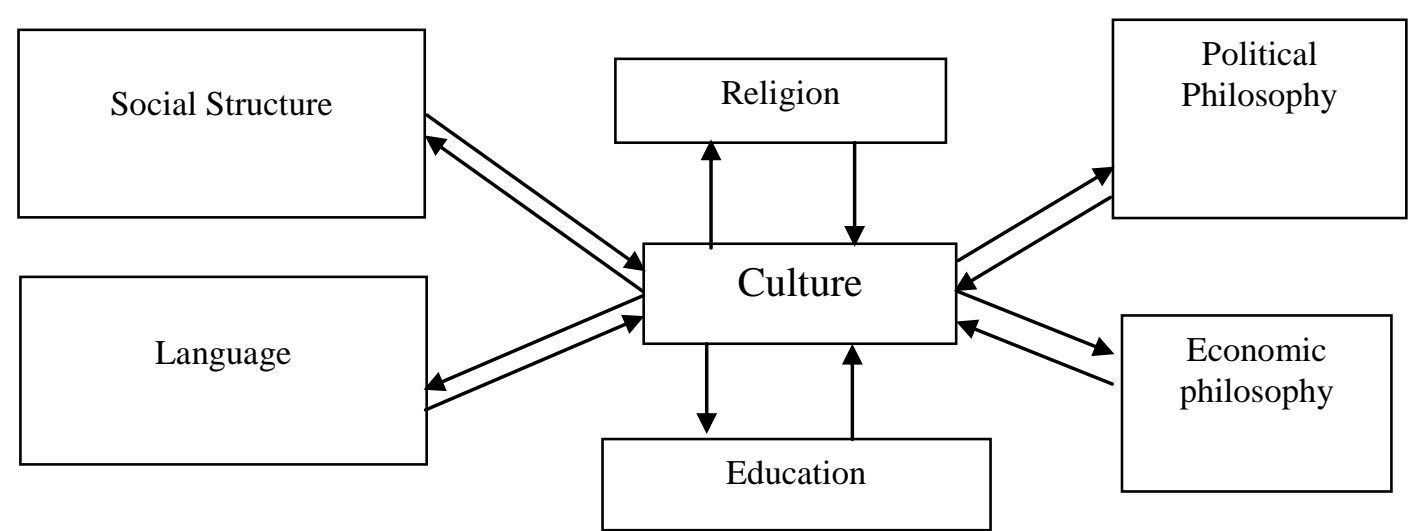

Figure. 1 The determinants of culture

Religion

Source: Adapted from Hill (2009)

Religion entails the shared beliefs that are associated with the sacred philosophy. Within religion lies the ethical behaviour which depicts morality or immorality as a common denominator that shapes human behaviour. Arising from the link between ethics and religion, the majority of ethical systems draw to a large extent from religions giving birth to what is referred as Christian and Islamic ethics (Steger, 2009).

\section{Political Philosophy}

Political philosophy refers to the type of political system which is in place in a country. There are different political systems - democracy and totalitarianism. Totalitarianism can be further divided into four variants (Cherunilam, 2003). Political systems are critical because they shape the economy of a country and therefore affect international business. Political systems are adopted because a country believes that a particular system is important for its citizens, it is a way of looking at life and therefore shaped by culture (Varghese, 2011:101).

\section{Economic Philosophy}

The economic philosophy is the way the economy of a country is managed and the general direction it is taking. The adoption of a particular economic philosophy is determined by perceptions of what is good and relevant in a particular country. As we have just learnt culture determines the way we look at life. There are three major economic systems - communism, socialism and capitalism. Some countries do not use any one particular system but adopt a mixture of systems. These systems are called mixed economic systems.

\section{Education System within a Country}

Education plays a key role in a country by acting as a medium through which individuals within society learn several languages, as well as mathematical skills, to enhance the development of a modern society (Steger, 2009). Through education, members within society can socialise with younger generations gradually instiling the values and norms which the society subscribe to. Values and norms are aspects or elements which can be taught directly and indirectly at school (Cherunilam, 2003). Schools play a key role by teaching factual norms and ideas regarding society as well as the political nature of a particular society. 
Schools also teach cultural norms, though indirectly by demostrating aspects such as obedience, neatness, honesty and punctuality.

\section{Language spoken by the Nation}

Language refers to either spoken or unspoken language. Language plays a more critical role as opposed to merely enabling people to communicate with each other (Steger, 2009). Thus, language captures the way society and individuals view and perceive the world. Through language members of a society can be directed to certain features of the world rather than others (Steger, 2009).

\section{The Legal Environment}

The legal environment of business refers to the external environment of business and includes facts such as the rule of law and matters related to general rules and regulations regarding doing business in respective countries (Ragoza, 2013). The legal environment of business can make or destroy a firm that intends to go international if managers fail to deal with such laws (Hill, 2009). The international legal environment is dynamic, complex and varies significantly from one country to another. The majority of regulations on the legal environment are targeted on export and import, transfer pricing, taxes, regulation of corrupt practices, embargoed nations, antitrust, expropriation and distribution of equity, patents and trademarks. The key issues in the legal environment are jurisdiction, resolution of disputes, and terms of access. The countries laws also cover the import/export of goods into and outside a country. The import/export regulations are also called the terms of access.

\section{Terms of Access}

The phrase "terms of access" means all the conditions that apply to the importation of goods from a foreign country (Varghese, 2011:101). The major instruments covered by this phrase include import tariffs, import quotas, local content requirements, administrative barriers, etc. Import tariffs: An import tariff refers to a tax levied by a country on goods or services imported into a particular country. There are two types of tariffs - a specific tariff and an ad valorem tariff. A specific tariff represents a fixed monetary amount for a given unit of import. For example, R15 per kg of imported fish. An ad valorem tariff is made up of a percentage of the value of imported sugar. For example, $10 \%$ of the value of imported milk. Import quotas are a direct restriction on the quantity of some imported product (Varghese, 2011:101). This is regulated and implemented through import licences, issued to individuals and firms. A quota is similar to a tariff in the sense that it reduces imports and raises domestic prices. However, quotas are different from tariffs in the sense that it places a cap on the number of imported products. Once quotas have been exhausted, there may be no further import of that good in that year.

\section{Non-tariff Barriers}

With the pressure to reduce tariffs quite strong between nations, attention has naturally turned to non-tariff obstacles to trade (Ragoza, 2013). A non-tariff trade barrier refers to the measure that provides a limitation to the sale of products in a foreign market. The main non-tariff barriers includes:

Local content requirements: Local content requirements result from government legislation forcing a certain portion of a product to be produced locally (Varghese, 2011:101). As an example, suppose that the company wants to set up a plant in Kenya. The Kenyan government may insist on at least $10 \%$ of the components being manufactured locally. The idea is to support domestic industries.

Administrative barriers: Administrative barriers are another form of restricting imports, supporting domestic producers and boosting exports. By applying this approach, rules and regulations for classifying and valuing commodities as a basis for levying import duties can be administered in a way that makes 
compliance harder and exorbitant so that the firm involved give ups and considers markets with fewer hurdles.

Selective monetary controls - This refers to the use of exchange rate that discriminate against certain countries of goods or services which then distort trade. The use of selective monetary policies is an example of discretionary monetary control barriers to trade. These regulations in effect raise the price of foreign goods by the cost of money for the term of the required deposit.

Restrictive technical regulations - These include physical limitations of goods into a country and include aspects such as anti-dumping rules, and rules on safety regulations. The focus of the regulations is mostly to keep out foreign foods, while others are directed towards legitimate domestic objectives.

\section{The Economic Environment}

The economic environment includes the nature and structure of an economy, economic policies, and the state of development of an economy, the income, the assets, and the economic systems in place in a country. Issues such as inflation, recession, and exchange rates that influence the prosperity of the firm are all part of the economic environment. An economic system of a country describes how society allocates its scarce resources towards the production of goods and services (Ferrell \& Hirt, 2003). Different countries have different systems, which they use to resolve the allocation of resources. It is important to note that the main economic systems are communism, socialism and capitalism.

Socialism and communism are closely related. In socialism, the government owns and operates basic industries that include water, electricity and telecommunications, postal services, health care, electricity and water utilities, banking, some manufacturing firms and the rest are owned by individuals and businesses. As with communism, the government uses central planning to determine the goods required by the citizens, and how these goods are manufactured and distributed. The majority of countries are democratic, hence they allow individual freedom. For example, countries such as France and Sweden are regarded by many as democratic. In such countries, citizens vote for political offices, but central planners usually make decisions about what is best for the nation. Socialists are driven by the belief that their system allows a higher standard of living than other economic systems. Socialist economies advocate egalitarianism - which is the equal distribution of income and social services. Taxes and unemployment are generally higher in socialist countries.

A capitalist system is aligned to free enterprise systems. This is an economic system where individuals are free to own land and undertake economic activities without government interference. In a capitalist economy, the market forces of supply and demand determine the goods or services to be produced. For example, countries such as the United Kingdom and Canada represent a capitalist society.

There are two forms of capitalism: pure capitalism and modified capitalism (Hill, 2009). Pure capitalism, also referred to as a free system, means government does not intervene on all the economic decisions in the country (Hill, 2009). However, it is critical to note that it is not possible for a country to practice free capitalism. The majority of nations follow a mixed economy system, which has an element of freedom and government control. The foreign exchange (forex) market is a market where currencies may be exchanged or traded (Hill, 2009). The forex market is similar to any other type of market where trading occurs. In a stock market, one is able to buy and sell shares of stocks or publicly listed firms.

Payment is in the form of money (either cash or other forms of money such as electronic payments and clearing) (Hill, 2009). In this sense, a foreign market is not different. In a forex market, payment is effected using money. The difference is that the goods being traded are also money (Ferrell \& Hirt, 2003). The transaction is reflected with an exchange rate. An exchange rate may be thought of as the price of the 
foreign currency being traded. The assumption here is that the home country currency is the money being used to effect payment, and the foreign currency is the item being traded.

\section{The Political Environment}

The fact that politics determines both business and police directions goes to demonstrate the importance of the political environment to business (Hill, 2009). The political environment encompasses the political system of government within a country, the constitution and the government environment, the policies and regulations. According to Slaughter and May (2012), these factors vary from one nation to another. However, of more importance to this study is the fact that these different political systems affect business considerably. A political system that can be either democratic or totalitarian representing a system of government in a nation (Hill, 2009). Africa has experienced some changes in the political systems of several countries including the Democratic Republic of Congo, Zimbabwe, Malawi, Mozambique, Nigeria, Sudan, Rwanda and several others, to the extent that firms considering international expansion have to consider the systems in the respective countries.

According to Ragoza (2013), democracy entails a political system in which the government is by the people for the same people. Through democracy, citizens should be directly involved in decision-making, a belief that underpins the democratic principles. In a democracy, citizens elect individuals through a general election (Ferrell \& Hirt, 2003). The members selected will represent citizens in parliament with the representatives making decisions on behalf of the citizens. In countries that are fully totalitarian, the government owns and control all the natural resources (Hill, 2009). In this type of government, dictatorship is widespread, and those who are seen to challenge the rulers are victimized.

The focus for business managers in political systems is firstly to appreciate that there is political risk capable of hindering business growth. In a politically poised environment, there is a likelihood the forces within politics will hinder business growth cause. It is important for a manager to understand political systems in order to assess the level of political risk to his/her business (Shekeshnia et al., 2014). Changes in government administration and the emergence of violence, as well as the impact of cultural divisions, can bring uncertainty to business. For example, the current uncertainty in Liberia and Rwanda, Zimbabwe, and the violence of Somalia testifies to a political risk that affects business expansion into such countries (Ferrell \& Hirt, 2003).

\section{Technological Environment}

The technological environment depicts the advances in technology by a country (Slaughter \& May, 2012). The firm that decides to go international must deal with technological strategy if they are to remain competitive. Technology is a social determinant of the success of a firm, as well as the economic and social development of a nation (Cherunilam, 2003). Technology includes tools, machines, as well as the software required to advance business activities (Cherunilam, 2003).

Technology is an important factor that is used in evaluating the international competitiveness of nations as well as firms. There are a number of technologies that contribute to a country's competitiveness (Ferrell \& Hirt, 2003). One of these is Information Technology (IT) and advances in telecommunications. Electronic mail (e-mail) has increased the possibilities for personal, inter-firm, as well as international communication. The Internet has allowed for rapid dissemination of significant amounts of large amounts of information. The area of e-commerce and e-business offers the potential for substantial increases in the customer base for companies and huge marketing costs.

Innovation is an important factor that provides competitive advantages to companies and nations (Shekeshnia et al., 2014). The entrepreneur, who is the innovator, is the central figure in an economy. Innovation may take any of the following forms: the introduction of the product; the use of a new product 
for production; the opening of a new market; the conquest of a new supply of raw material supply and the reorientation of an industry. In the business context, innovation may be defined as "the technical, industrial, and commercial steps, which lead to the marketing of the new manufacturing of products and to the commercial use of new technical processes and equipment." Technological change is 'one of the principal drivers of competitions. It plays a major role in industry structural change as well as in creating new industries. It is also a great equalizer, eroding the competitive advantage of even well-entrenched firms and propelling others to the forefront (Shekeshnia et al., 2014).

Many of today`s great firms grew out of technological changes that they were able to exploit. Of all the things that can change the rules of competition, technological change is among the most prominent. Innovation is the key weapon in achieving a sustaining competitive advantage. In order to compete successfully, it is vital that a firm uses the most appropriate technology to produce and distribute its product or service (Hill, 2009).

It is therefore clear that a manager in the international environment is faced with a range of issues that the manager in a domestic business never faces. The manager ought to decide where in the world to site the firm's production activities in order to minimize costs and add value. The manager must also decide how best to coordinate and control the firm's dispersed production activities. Managers must decide which foreign markets to enter and which ones to avoid. In addition, this is no small decision in a rapidly changing international environment.

Managers must also decide on the most appropriate strategy to enter the chosen market. The market entry mode is important because it has significant implications for the long-term health of the firm. Once in the foreign market the manager must understand the rules governing the international trade and investment system in dealing with government restrictions on international trade and investment. More importantly, the manager must develop strategies dealing with such interventions.

\section{Strategies for Interactions Business Expansion}

According to Goldstein et al., (2017:39), there are various theoretical models which were developed by various authors in pursuit of knowledge on how best firms can go international with a focus on the behavior towards the prevailing macro environment rather than industrial activity. Gaining this kind of knowledge would assist those companies intending to go global in terms of the kind of decisions and strategies towards averting the challenges thereof. About four decades ago, Johanson and Vahlne (2002) propounded the "Stages" theory as the gateway to firm internationalization.

\section{The Stages of going global}

Johanson and Vahlne (2002) undertook a study on Finland firms that sought to go global at that time. The study revealed a landmark evolutionary process for internationalizing a business, which is still applicable to contemporary international practice. The stages theory argues that in the majority of cases firms start the internationalization process through direct exports to other countries. The process is usually backed by independent agents abroad who do all the groundwork. Gradually, subsidiaries are developed to sell the product abroad. In the fourth and final stage, the production/manufacturing facility is established abroad. It is critical to note that the primary intention is on the first three stages which is on selling the product abroad.

\section{Stage 1: The passive response}

Radziwill and Vaziova (2015) highlights that a firm has to pass through different stages of development before becoming a truly global player. A local firm begins the global business through exporting or importing. Exporting means selling a company's products outside the country while importing entails 
buying goods/services outside the country boarders (Shekshnia, et al. 2014). This company entered most of the African markets through exporting as it relied on international sales without opening a manufacturing plant elsewhere abroad.

\section{Stage 2: Initial overt entry}

Pavlova (2014) highlights that second stage, referred to as the initial overt entry, depicts the link up by the firm with local dealers and distributors for the purposes of selling the products. It is important to note in the previous stage, the firm sold its products directly to buyers without agents. In an initial overt entry, the dealers or distributors come into play (Pavlova, 2014).

\section{Stage 3: Established international operations}

Stage three depicts the actual involvement of the firm where it begins to carry out its activities on its own (Radziwill \& Vaziova, 2015). According to Radziwill and Vaziova (2015), the firm could enter directly or collaboratively to offer its own resources in the target country, or it can collaborate with other firms. The options for market entry modes are:

\section{Licenses}

According to Hill (2009), licensing entails the buying of rights by a foreign country to use to manufacture its own products for a given period, which could be renewable. Goldstein et al., (2017:39) highlights the advantages of licensing as allowing a firm to access technical knowledge in a foreign land without undergoing rigorous processes. Thus, cutting off high start-up costs, as well as risks associated with the setting of its own operations in a foreign country. Radziwill and Vaziova (2015) argue that licensing helps in reducing the political and economic risks of doing business in a foreign land.

\section{Franchising}

Hill (2009) defines franchising as business arrangements where a firm sells limited rights to foreign companies to use brand name and service expertise with the franchisee paying royalties. In franchising, the firm avoids start-up costs and the risks of setting up operations in a foreign market, as well as avoiding the economic and political risks that may arise in the foreign country unknown to the firm.

\section{Foreign Subsidiaries}

According to the IMF Centre (2015), a foreign subsidiary is when the firm takes $100 \%$ ownership of the company in the foreign market. The firm may choose to set-up a green field site, i.e. building up the entire operation from scratch, or it may resort to acquisition of an existing company in the foreign market. The advantages are that the firm has full control of the operations, its technology and expertise. It will be able to exploit location economies of scale, experience effects. It will also be able to engage in global strategic coordination.

\section{Research Methodology}

This study is exploratory and qualitative in nature approached from a phenomenological paradigm, with the purpose of identifying and proposing factors to be considered towards investigating the international business growth challenges faced by a South African manufacturing company. 


\section{Target Population and Sampling}

According to Collis and Hussey (2009:62), a population is any precisely defined body of people or objects under consideration for research purposes. The target population for the study is the number of local and international managers in the respective countries across Africa. From the target population of 22 managers, only eight managers were selected to participate in the study. This study used purposive sampling which is non-probability sampling technique to select eight managers from 22 . The managers were selected with the aim of taking only those managers that would provide answers needed for the study. Thus, the following exclusion/inclusion criteria was employed:

Only permanent managers were selected;

Only managers engaged in international business with at least five years' experience and

Only managers who physically posted abroad formed part of the sample.

Based on the above, this study employed the interview as the research instrument for the study. Khan (2014) believes that interviews are suitable for smaller samples. The interview covered the following:

Section A: Biographical information;

Section B: International business opportunities across Africa;

Section C: The factors affecting the company's international business growth into Africa;

Section D: The extent to which the factors hinder affect growth into Africa.

The questionnaire consisted of four main themes.

\section{Pilot Study}

Leedy and Ormrod (2005) define a pilot study as the process of pre-testing the research instrument in order to detect weakness and strengths so that weaknesses can be corrected on time. The pilot study was done on only two participants who did not participate in the full study and corrections noted were affected. For example, the number of questions on the interview guide was reduced from 15 to 10 without compromising the validity and reliability of the interview guide. This was because the interview lasted for almost an hour each, which was deemed too long. In addition, the original interview guide had questions that were not aligned with the objectives and after the pilot study, the specific question were slotted under the respective objective to ensure alignment as well as assurance that all the objectives are addressed. Further, the pilot study revealed that demographic data such as experience and race promoted biasness, and were thus removed from the final interview guide.

\section{Data Analysis}

Descriptive qualitative data was collected from interviews. A non-quantifying approach was taken in analysing this data and no statistical analysis was considered relevant (Collis \& Hussey, 2003). In particular, the data analysis method used in this study was thematic, which enabled the researcher to move the analysis from a broad reading of the data collected from interviews towards discovering patterns and developing themes.

\section{Validity and Reliability}

Instead of depending on validity and reliability, trustworthiness in qualitative research is ascertained based on credibility, transferability, dependability, and conformability (Lietz \& Zayas, 2010). In this study, credibility was obtained through ensuring that data collected and findings from the study tightly link back to participants' own experiences, insights and evidence in international business, with particular emphasis on the challenges facing the company. To ascertain this, only experts in international business as managers qualified as participants in this study. The researcher also persistently pursued interpretations of the various aspects of doing business across Africa from the opinions of the participants. For example, participants 
were requested to narrate on the challenges of doing business across Africa and comment on how the challenges could be reduced. Moreover, for referential integrity, the researcher made extensive interview notes and where there was further engagement with participants after the interview, any insights would be confirmed via email and such emails would be attached to the interview notes of the corresponding participants respectively. Moreover, to reduce the researcher's bias, data collected from interviews was triangulated with the literature review and a sample of real international business.

\section{Limitations of the Study}

The main limitation of the study was the insufficiency of literature available in the area of international business growth challenges. Another limitation was the unwillingness of certain managers to participate despite being experienced and involved in international business due to their busy schedule. The researcher had to be flexible in terms of meeting times for interviews. The sample size was very small, which raised validity concerns.

\section{Ethical Considerations}

The researcher attended to the following ethical considerations as per Saunders, Lewis and Thornhill, (2009:202):

Seeking permission to conduct the study from the company. In this study permission was granted before data collection. Ensuring privacy of participants was taken into consideration. Ensuring confidentiality of participants by not disclosing the data collected, as well as storing the data collected in a secure lockable cabin for a reasonable period stipulated by the college. Ensuring that there is informed consent of participants - participants were not coerced to partake in the study, as they were free to disengage from the study at any time without negatively affecting the study process and outcome. All interviewees signed a consent form.

\section{Result}
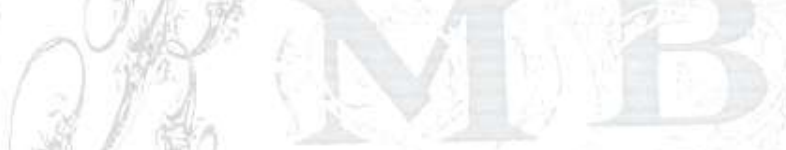

Seven out of eight participants that were purposively selected were interviewed, giving a response rate of 87.5\%. According to Saunders et al., (2016:341), a good response rate serves as a potential for valid and reliable findings. There were no participants younger than 30 years, with most above 30 years suggesting that the company's managers are in the middle-age group. Most participants were male, to a ratio of 6 to 1 .

\section{Results based on objectives 1: To assess the company's international business opportunities across the African continent}

This was the first objective of the study, which aimed at assessing the company's international business opportunities across the African continent. In an attempt to address the objective three interview questions were answered by all the participants with data gathered from each question thematically analyzed leading to emerging themes. In the following section, a discussion of the results on each question is presented.

Question 1: The company has been in existence for many years doing business across Africa. Could you please identify and explain the regions/countries, which the company has opened branches?

This was the first interview question for the study, which sought to identify the regions or countries, which the company entered into over the years. Data gathered on the question is presented below. Data were thematically analyzed upon which two themes emerged. The themes include lack of manufacturing plants/firms across Africa and selling of products to most countries across Africa as part of trade. 


\section{Lack of manufacturing plants across Africa}

Participants revealed that the company does not have physical manufacturing plants in other African countries besides South Africa. According to participants, the company has its footprint in 30 countries with South Africa representing Africa. However, the company has markets in almost every African country. Participant 3 and 6 emphasized that the current situation where the company has its manufacturing plants in South Africa when it has operated for several years was a clear demonstration that there was no need to have a physical manufacturing plant elsewhere.

\section{Sells products to most of the countries across Africa}

Participant revealed that the company's brand has reached every country in Africa just by mere trading. Thus, the company sells products from South Africa to the rest of the continent. Participant narrated that, as an international business development manager, his task was to market the brand throughout Africa, which has since increased its footprint across the continent. Participant 4 argued that from a business sense, the company was in good position as it has captured the African market by merely trading its brand without necessarily making a permanent move to establish a manufacturing plant. Under this theme, the finding suggests that all is well with expansion through selling the company brand.

Question 2: Explain the opportunities and challenges the company has encountered in the respective countries over the years?

This was the second interview question under objective one. The question aimed at gathering participant views on the opportunities and challenges, which the company encountered over the years across the African continent. Mindful of the findings under question one, which revealed that the company does not have physical manufacturing plants across Africa, instead, it operates distribution centers, this question is coined to establish the challenges that arise through the distribution centers. Three themes emerged from the interview narratives, namely: increasing use of information technology across Africa, monopolistic tendencies and foreign currency as opportunities arising from the company's expansion across Africa. The three themes are discussed below.

\section{Increasing use of information technology and innovation across Africa}

Regarding increasing use of information technology across Africa, participants highlighted that the company's capacity to expand was a reality due to the emergence of the information technology age which saw the paper printing industry booming. The finding under this theme suggests that information technology was a huge opportunity for the company's expansion efforts across Africa.

\section{Monopolistic tendencies}

Regarding monopolistic tendencies it was revealed that, the company's efforts to expand was a culmination of monopolistic tendencies, which emerged in its favor. Participants argued that the company has become a monopolistic player in South Africa and Africa at large, which ultimately becomes an advantage.

\section{Foreign currency}

Regarding foreign currency, participants revealed that the company had an opportunity to raise foreign currency as it expanded into Africa which ultimately led to double benefits as the company further expanded into Africa. While foreign currency was an opportunity for the company in South Africa, participants felt that international expansion meant that it needed to make certain payments in foreign currency, which could be very exorbitant. For instance, in countries such as Zimbabwe where inflation sometimes rises to over 50\%, raising foreign currency could end up in loss of business. 
The finding under this theme is two-fold - one where the company raised foreign currency due to international expansion with the other where the process of raising foreign currency turns tragic leading to a loss in doing business due to exchange rates issues. Secondly, is the question of providing insurance against foreign exchange risk (Varghese, 2011) and in this context, the company managers on a global front ought to comprehensively understand the meaning of foreign currency in relation to how it affects the organization.

\section{Challenges across Africa}

Aligned to question two, this section identifies and discuss the challenges that the company face in expanding across the African continent. The four themes, include politics, language, custom duties and corruption as challenges faced by the company expanding into Africa. These challenges are discussed below.

\section{Politics}

Participants revealed that politics was a serious challenge to the company's expansion efforts across the African continent. A follow-up question on what was meant by referring to politics as a challenge to the company's international expansion efforts, participant 6 revealed that polices entailed the decisions, rules and policies made by the political government in respect of doing business. For instance, participant 6 revealed that there was a time when the company decided to establish a manufacturing plant in one of the SADC countries but failed due to political meddling. For example, the government in question passed a bill that required all foreign-owned firms to own $45 \%$ of their firm with 51 owned by citizens of the country. Participant 4 indicated much of the challenges they face were aligned to political pressure seeking to stop foreign business from entering their market. For example, most of the registration requirements make it almost impossible for foreign firms to register thus inhibiting foreign expansion. Participant 5 and 3 revealed that matters such as the tax system and the tax percentages matter a lot. For instance, some countries have the highest tax in Africa and the world, meaning that foreign firms pay a lot as corporation tax. For the company, achieving such as milestone of exporting to almost all the countries in Africa speaks volumes of its drive on the marketing strategies. However, much more in the sense of establishing manufacturing plans, joint ventures, licensing or strategic alliances could have been done had it not been for the pressure from the political environment.

\section{Language}

Language also emerged as challenge to the company as it expanded across the African continent mindful of the fact that Africa has diverse languages which could serve as barriers to business communication. Participant 4 explained that doing business in countries that speak a different language was a problematic particularly in French and Portuguese speaking countries. The finding under this section identifies language a hindrance to the company's international expansion. Thus, the finding aligns with Steger (2009) who argues that language played a critical role as it captures the way society and individuals view and perceive the world.

\section{Custom Duties and Quotas}

Participants identified custom duties as a challenge to the company's international expansion across Africa. According to participant 3, the tariffs charged on all foreign goods and also known as, "custom duty" was a hindrance to the company's expansion across Africa as it inflates the price of the product as a means to protect local industries. Participant 5 highlighted that some countries charge tariff rates that are too high making the product more expensive that domestic goods. Participate seven narrated that in certain instances, physical limitations in terms of quantities are imposed on certain products to completely limit imports to a certain quantity. According to participant 7, some countries in Africa give the company 
specifications of the tonnage that must be allowed into a country presenting a hindrance to business expansion.

\section{Corruption}

Corruption also emerged a challenge affecting the company's operations across the African continent. According to participant 3, African politicians and officials have a tendency to request bribes to allow foreign deals to be signed and due to the company's policy on anti-corruption; potential business opportunities have been lost. According to participant 5, corruption was the enemy number one for doing business in Africa especially when a business intends to move from one country to another.

The company has experienced challenges in the west and some parts of Southern Africa, which has seen some reduction in the volume of business in these regions. According to participant 2, corruption in certain West African countries has hindered the business expansions. The finding under this theme suggests that corruption in Africa was real and rife and has a negative effect on the company's expansion. The study findings suggests that company managers who are on foreign assignment are often tempted to bribe officials in the respective countries in order to influence relaxation of rules and regulation.

\section{Question 3: Explain how the organization has dealt with the challenges}

This question sought to understand participant's views on how to deal with the challenges faced by the company. Interview narratives on this question are presented below.

Regarding the resolve on the challenges, there emerged three themes, which include: compliance with respective rules and regulations, employing the local people and engaging in corrupt tendencies. Each of the themes are discussed below.

\section{Compliance with respective rules and regulations}

To address the expansion challenges across Africa participants revealed that the company complied with the respective rules and regulations, in the particular countries as a means to enter foreign markets. Participants revealed that Africa has business communities that include SADC, ECOWAS, COMESA and several others. The fact that the company has managed over the years to expand into Africa, suggest that it complied with the rules and regulations for doing business as evidenced by the findings.

\section{Employing local people in the distribution centres}

To address the language barrier, participants indicated that, employing local people to manage the company's distribution centres in the respective countries would reduce the language hindrance. Participant 3 argued that, it was difficult for the company doing business in French speaking countries, lest the organization employed local citizens who speak French.

\section{Corruption Tendencies}

Participate 6 highlighted that a corrupt-free environment was inevitable. According to participant 4, the company provides donations in kind to respective countries as a way of getting return in the form of being allowed to conduct business in their country. Participant 5 highlights the concept of corporate social responsibility as being indirect corruption. Drawing from the narratives under this theme, the company, to a certain extent, engages in corrupt tendencies and further, it uses corporate social responsibly as a motivator to the countries that gives them business. 
Results based on objective 2: To identify the factors affecting the company's international business growth into Africa

The second objective of the study sought to identify the factors that affect the company's international business growth into Africa. Doing business across Africa is bound to succeed or fail depending on various factors. Two questions were asked from the seven participants. The following section presents data on each question.

Question 4: Identify and explain the factors that in your view affect the South African company's international business expansion

The aim of the question was to list and explain the factors that affect operations across Africa. Interview narratives under the questions are tabulated below followed by a detailed analysis of each theme. The factors as revealed by participants include political, ecological, economic, technological, social and cultural environment of business with each of the factors discussed below.

\section{Political Environment}

The political environment emerged as a factor that affect doing business across the African continent. According to participant 2, the political environment can make or destroy efforts to grow and expand the business. Participant 7 noted that a country is in the hands of politicians and if politicians make conducive laws, that promote foreign investments, the easier it becomes for business international expansion. The finding under this theme suggests that the company had mixed fortunes across Africa where it expanded and grew extensively while in other countries it struggled due to the political environment. If the company is affected by the political factor as the case, it is paramount to view the political factors as one that encompass the political system of government within a country, and this includes the constitution and the government environment as well as the policies and regulations.

\section{Ecological Environment}

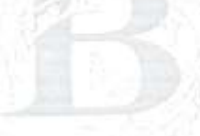

The ecological environment also emerged as a factor affecting international business growth into Africa. This is so particularly for the company, mindful of the fact that the ecological environment entails the efforts that are meant to preserve the environment. Even in South Africa, which is the African head office, the company is required by law to preserve the environment in across South Africa's manufacturing plants. Participant 7 noted that across Africa, the company is only required to sell products that are environmental friendly while the issue of polluting the environment are addressed at the African head office.

\section{Economic Environment}

Participants revealed the economic environment as a concern for the company's international growth and expansion. Economic environment here relates to the environment in the respective countries to which the company operates. Thus, participant 5 noted that inflation, interest rates and business stability mattered most on the company's expansion. According to participant 6 , rising interest rates and inflations hindered the company's products in Zimbabwe, Zambia and Malawi, which saw sales dropping. In situations where an economy is stable, business tends to steadily grow. Thus, participant 3 explained that business in Botswana, Angola and Gabon proved good as the inflation levels were very reasonable. The finding under this theme suggests that the effect of the economic environment on the company varied from country to country. In this study, the company comes from a constitutional democracy as the guiding torch for business operation and activities while on the other hand, the rest of Africa's democratic systems leave a lot to be desired. Moving from South Africa, to do business in a different economic set could be both advantageous and disadvantageous depending on the state of economic system in the country in question. 


\section{Technological Environment}

Technological environment emerged yet another factor affecting the company's business growth and expansion into Africa. According to participant 3, products manufactured by the company and sold across Africa, were driven by technology. The finding under this theme suggests that the technological environmental had a huge effect on the company's expansion. Technology includes the level of technological development, the speed with which new technologies are adopted and diffused, appropriateness and policy framework in inter and intranet (Ferrell \& Hirt, 2003).

\section{Social Environment}

According to participant 5, the company's growth and expansion was negatively affected in povertystricken countries such as Malawi and Burundi, while it did relatively well in countries such as Nigeria, Botswana and Gabon whose poverty levels are considered to be above the poverty datum line. Again, the effect of the social environment on the company's expansion and growth varied from country to country, but in the overall, the finding suggests that they suffered a social blow across the continent.

\section{Conclusions and Recommendations}

The findings from primary study relate to the actual findings from the interviews. The 23 themes, which emerged are documented under the respective objectives as findings aligned to the relevant interview question.

Objective 1: To assess the company's international business opportunities across the African continent

The findings revealed that the company:

Did not open or establish manufacturing plants across Africa but rather,

Conducted its business by selling or exporting products to most countries across Africa.

On question 2, which required participants to explain the opportunities and challenges the company encountered in the respective countries over the years. The findings revealed that the company enjoyed:

Increasing use of information technology and innovation across the African continent;

The benefits that arise when a firm acquires or gains monopolistic tendencies and

Acquired foreign currency.

At the same time, the company faced serious challenges, which include;

Political interference during the conduct of business across Africa;

Language barriers when doing business across Africa;

Imposing of stringent custom duty and quotas and;

Corruption during cross-border trading as goods enter foreign markets.

Regarding Question 3, which required participants to explain how the company dealt with the challenges, the study, revealed that the company addressed the challenges by:

Complying with the rules and regulations imposed by the respective countries; Employing the local people as a means of addressing the language barrier and;

Engaging in some corrupt practices (bribery) in order to motivate for business deals where necessary. 
Objective 2: To identify the factors affecting the company's international business growth into Africa

One interview question was designed to address the objective. Regarding question 4, which required participants to identify the factors affecting the company's international business expansion, the study revealed that the organization's expansion efforts were hindered by;

The political environment in the respective countries;

The ecological environment;

The economic environment;

The technological environment and;

The social environment.

Objective 3: To assess the extent to which the factors hinder international business growth into Africa

Three interview questions were designed to address the objective. Regarding question 5, which required participants to select the factors, which affected the company in the worst of terms, the study revealed that:

The effect of the factors varied from country to country, however,

The ecological environmental factors hindered the company's operations mindful of the fact that the organization needed to comply with international standards when it comes to issues related to the environment in particular the greening management.

On question 6 which sought to understand the extent to which the company's international business expansion were affected, the study revealed that, the organization was affected:

To a minor extent as the company continued to export its product to almost every country in Africa despite the challenges and;

To a large extent in the sense that, the company failed over the years to build at least one permanent manufacturing plant in one of the countries.

On question 7 which required participants to share their thoughts on how the company could improve or enhance its intentional business operations, the study revealed that, the company could:

Enter into joint venture agreements in the respective countries they are currently exporting;

Enter or expand through licensing arrangements or;

Consider franchising as a business format.

\section{Conclusions}

Based on the above findings, the following conclusions were drawn under the respective objective.

\section{Objective 1: To assess the company's international business opportunities across the African continent}

Exporting, as an international business strategy can only be effective to a certain extent, however, with time it ceases to be effective, calling for the need for the international firm to construct manufacturing plants in the foreign land;

International business has the potential to create and resources, innovation and technology to both the domestic and home firms ultimately benefiting the country;

However, international business often face the challenge of political interference, language barriers, stringent custom duties and import quotas; 
Compliance with the rules and regulations in the respective countries is critical for international business success;

The unspoken and spoken language plays a critical role in international business with foreign firms advised to employing local citizens and

Despite being bad business practice, corruption is inevitable in Africa's international business as those at the forefront, engage in corrupt practices that include bribery.

\section{Objective 2: To identify the factors affecting the company's international business growth into Africa}

The company's international efforts, despite exporting across the continent, the international business efforts were affected by:

Political interference;

Adhering to the global and country's specific ecological environment;

The effect of the economy in the respective countries;

The state of technology in the respective countries and;

The state of poverty, crime, unemployment in the respective countries.

\section{Objective 3: To assess the extent to which the factors hindered international business growth into} Africa

Going international was no mean task for the company. However, countries across Africa have varied international business environments which the company needed to tap into. The extent to which the company was affected varied from country to country. In some countries international business was affected to a minor extent as the company continued to engage in meaningful business through export, while in some countries, business was tough which needed the permanent establishment of a manufacturing plant, which never was.

\section{Recommendations}

The following recommendations were provided, drawing from the above conclusion:

Based on the conclusion that the company relied on exporting over the years to penetrate African markets, the study recommends that the organization should take advantage of the relationship it has created with the African business community and consider negotiating with the respective countries located on strategic regions of the continent such as central Africa, Eastern Africa and Western Africa towards building a manufacturing plant in these regions as a route to physically move into the greater part of Africa.

Based on the finding that the company was to an extent affected by political interference, there is a need for the organization to formulate a policy on how managers on foreign assignments should react to the political challenge as a factor that could hinder business.

Mindful of the language barrier across the continent and the fact that, the company, ought to employ more of locals than foreign nationals, there is need for those on foreign assignment to undergo training on basic language for communication in the respective countries.

Corruptive practices should be discouraged at length and all managers on international assignments should be encouraged to comply with laws, rules and regulations in the respective countries.

In its value chain, the company ought to employ a cost effective means of production and manufacturing as a means of dealing with economic issues such as pricing and inflation. Besides exporting, the company 
should urgently consider joint ventures, licensing and franchising as alternative means of expanding into Africa.

\section{Scope for Further Research}

There are several firms based in South Africa that are doing business across the African continent. A similar study could be conducted on such firms in order to have a balanced view of what prevails across the international arena.

\section{Conclusion}

The aim of the study was to investigate the international business growth challenges faced by the company. Mindful of the fact that, the study sought to investigate international business growth challenges faced by the organization, it is certain that the objectives of the study were achieved, particularly if the company implement the recommendations.

\section{References}

Cherunilam, F. (2003). International marketing. Mumbai: Himalaya Publishing House Pvt. Ltd.

Collis, J. \& Hussey, R. (2009). Business research $3^{\text {rd }}$ Ed. New York: Palgrave Macmillan.

Donnison, P. (2008). Executive coaching across cultural boundaries. Development and Learning in Organizations. 22 (4), pp $17-19$.

Farrell, R. R. (2007). The future of globalization. The Real Truth Magazine. Available: http://www.realtruth.org/articles/070223-001-globalization.html; [Accessed: September 26, 2011 ].

Ferrell, O. C. \& Hirt, G. A. (2003). Business, a changing world. Vol.1. London: McGraw-Hill.

Freidman, T. L. (2008). The Dell Theory of conflict prevention. In T. L. Friedman, The world is flat. Boston: Bedford: Emerging a reader. Ed. Barclay Barrios.

Glasse, J. (2010). Foreign business in China political instability. Available: http://www.faqs.org/abstracts/Business-international/; [Accessed: March 17, 2010].

Goldstein, J. L., Rivers, D. \& Tomz, M. (2007). Institutions in international relations: Understanding the effects of the GATT and the WTO on world trade. International Organization. 61 (1), pp $37-67$.

Hamilton, L. \& Webster, P. (2009). The international business environment. New York: Oxford University Press.

Head, T. \& Sorensen, P. (2005). Attracting Foreign Direct Investment: The potential role of national culture. Journal of American Academy of Business, 6, 305-308.

Hill, C. (2009). International business: Competing in the global marketplace. Boston: McGraw Hill Irwin.

Hui, G., Neely, C. J. \& Higbee, J. (2008). Foreign exchange volatility is priced in equities. Financial Management. 37 (4), pp $769-790$.

IMF Center. (2005). Ten basic questions about globalization. Washington D.C.: International Monetary Fund. International Monetary Fund (IMF). (2008). Glossary of Foreign Direct Investment Terms. Geneva: IMF.

Johanson, J. \& Vahlne, E. J. (2002). The internationalization process of the firm: A model of knowledge development and increasing foreign market commitments. Journal of International Business Studies. 8.

Khan, R. (2014). Quantitative data analysis. In: F. du Plooy-Cilliers, C. Davis and R. Bezuidenhout, ed., Research matters, $1^{\text {st }}$ Ed. Cape Town: Juta and Co. Ltd, pp.131 - 146.

Leedy, \& Ormrod (2005). Practical research: Planning and design. New Jersey: Prentice-Hall.

Lietz, C. \& Zayas, L. (2010). Evaluating qualitative research for social work practitioners. Advances in Social Work, 11(2), pp. 188-202.

Pavlova, E. (2014). Fight against corruption in Russian and European discourse: Irreconcilable differences?, EU- Russian Paper, Centre for EU-Russian Studies, University of Tartu. 
Radziwill, A. \& Vaziova, Y. (2015). Improving the business climate in Russia, Working Papers, No. 1192, OECD Publishing, Available: http://dx.doi.org/10.1787/5js4hmd6kq32-en; [Accessed 2 February 2016].

Rogoża, J. (2013). The nationalization of the elite': Kremlin tracking official's foreign assets, OSW Analysis, OSW Warsaw, 10.04.2013. Available: http://www.osw.waw.pl/en/publikacje/analyses/201304-10/nationalisation-elite-kremlin-tracking-officials-foreign-assets; [Accessed 2 February 2016].

Saunders, M., Lewis, P. \& Thornhill, A. (2009). Research methods for business students. New York: Pearson.

Shekshnia, S., Ledeneva, A., \& Denisova-Schmidt, E. (2014). How to mitigate corruption in emerging markets: The case of Russia, Edmond J. Safra Working Papers, 36, February 6. Available at: http://papers.ssrn.com/sol3/papers.cfm?abstract_id=2391950\#\#; [Accessed 2 February 2016].

Slaughter (2012). Legal regimes governing Foreign Direct Investment (FDI) in host countries. Available: http://a4id.org/sites/default/files/user/documents/FDI\%20Legal\%; [Accessed 2 February 2016].

Steger, M.B. (2009). Globalization: A very short introduction. Hampshire: Oxford University Press.

Teal, M. E. (2007). Extent and causes of global shifts in manufacturing. Centre for study of African Economies, U.K.: Oxford University Press.

Varghese, N. (2011). Globalization and cross-border education: Challenges for the development of higher education in commonwealth countries. Kuala Lumpur: International Institute for Educational Planning (IIEP).

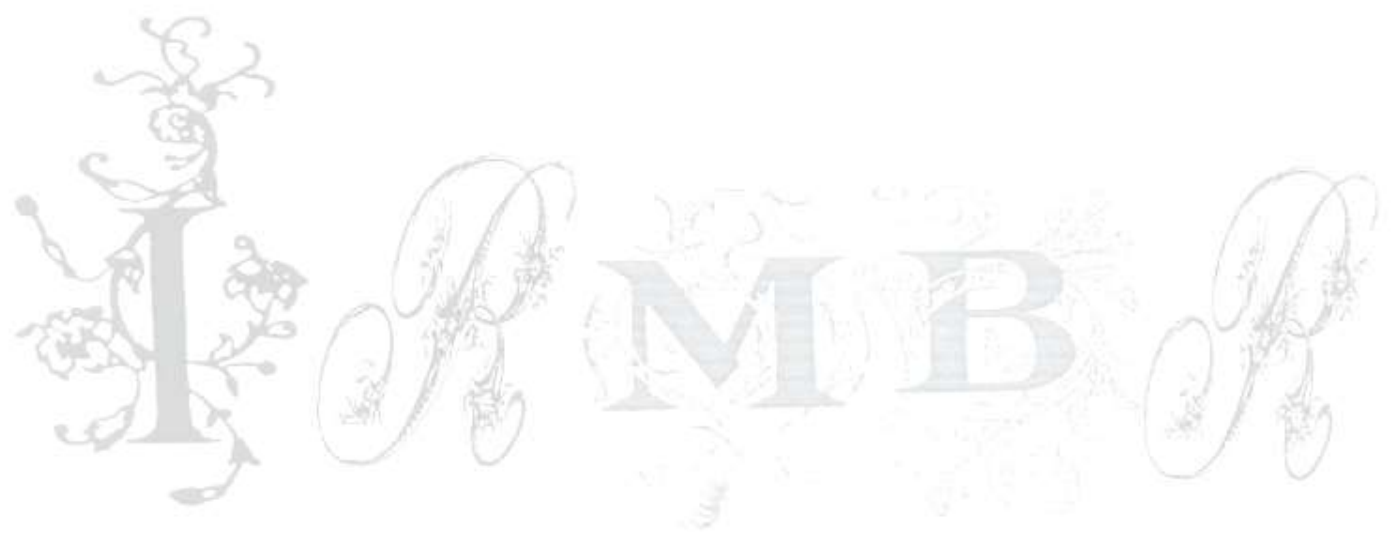

